\title{
Saving lives through voluntary blood donation: learning from medical students in ruvuma, southern Tanzania
}

\begin{abstract}
Background: Medical students present a high merit and potential source of blood in hospitals due to their medical knowledge, physiological potential by age however their use has been rarely described in southern Tanzania.

Objectives: The main objective of the study was to assess the knowledge, attitude, willingness for the future blood donation among medical students of southern, Tanzania.

Methods: A cross-sectional study to assess awareness, knowledge, attitudes, willingness and factors associated blood donation among medical students in Ruvuma, Southern Tanzania was conducted from March to June 2018. A self- administered questionnaire was used and data was analyzed by IBM Corp, SPSS Version 24.0.

Results: A total of 176 students were assessed at an average age of $25.8 \pm 3.6$ years. Eighty medical students (45.5\%) ever donated blood while among them $66(82.5 \%)$ of those being out of volunteering. About $46(57.5 \%)$ students had a repeated experience for blood donation. Majority of students had positive attitude toward blood donation 159 (90.3\%), often 135 (77\%) identified voluntary blood donation to be useful and $133(75.6 \%)$ were willing to donate in the future. Factors that were significantly associated with blood donation were age above $30(\mathrm{OR}=0.18, \mathrm{p}<0.001)$, male sex $(\mathrm{OR}=3.69, \mathrm{p}=0.001)$, past HIV screening $(\mathrm{OR}=2.59, \mathrm{p}=0.029)$, knowledge of one's own blood group $(\mathrm{OR}=4.86, \mathrm{p}<0.001$, and knowledge of the safe duration to donate a unit of blood $(\mathrm{OR}=2.42, \mathrm{p}=0.024)$.
\end{abstract}

Conclusion: Medical students present a high awareness, positive attitude, and high intention to donate blood to achieve the $\mathrm{WHO}$ goal for non-remunerated blood donation.

\author{
Volume 8 Issue 3 - 2020
}

\author{
Moshi Moshi Shabani,' Kauke Bakari \\ Zimbwe, ${ }^{2}$ Soha Sobhy, ${ }^{3}$ Bernard Mbwele ${ }^{4}$ \\ 'Medical Student, University of Dares Salaam, Mbeya College of \\ Health and Allied Sciences, UDSM-MCHAS, P.O Box 608, Mbeya, \\ Tanzania \\ ${ }^{2}$ Department of Pharmacy, Ocean Road Cancer Institute \\ (ORCl), P.O Box 3592 Dar-es-Salaam, Tanzania \\ ${ }^{3}$ Barts Research Centre for Women's Health, Queen Mary \\ University of London (QMUL), London, UK \\ ${ }^{4}$ Department of Epidemiology and Biostatistics, University of \\ Dares Salaam, Mbeya College of Health and Allied Sciences, \\ Tanzania
}

Correspondence: Bernard Mbwele, Department of Epidemiology and Biostatistics, University of Dares Salaam, Mbeya College of Health and Allied Sciences, Vijiji International, Mawenzi Road, P.O Box 7823, Moshi Tanzania.Tel +255 755 513858 Email benmbwele@gmail.com

Received: May 06, 2020 | Published: June 30, 2020

Keywords: saving lives, voluntary blood donations, medical students, Africa. Tanzania

Abbreviations: AJUCO, archbishop james university college; MOHCDGEC, ministry of health community development gender elderly and children; NBTS, national blood transfusion services; SPSS, statistical package for social sciences; UDSM-MCHAS, university of dar es salaam - mbeya college of health and allied sciences; VNRBD, voluntary non-remunerated; WHO, world health organization

\section{Background}

Blood donation is a vital health care practice needed for blood transfusion in a broad range of clinical services like cardiovascular and transplant surgery, massive trauma therapy, hematological malignancies, pregnancy-related complications and severe childhood anemia. ${ }^{1}$ Unfortunately, there is a challenge for country-level availability of blood in most of low and middle income countries. ${ }^{2}$ The World Health Organization (WHO), estimates that about 108 million blood donations are collected globally every year. Half of the global volume of blood is collected in high-income countries and is to less than $20 \%$ of the world's population. Again, the average blood donation rate is 9 times higher in high-income countries than in lowincome countries. ${ }^{3}$

It is a principle, for any country to meet the minimum demand for blood, collection should be at least from $1 \%$ of the population to meet a nation's most basic requirements for blood. ${ }^{4}$ This is an extremely easier goal to be archived but surprisingly it is less achieved by most of developing countries. Developing countries particularly those in
Africa require blood to effective management of pregnancy-related complications, postnatal care, trauma, severe childhood anemia and hematological conditions. ${ }^{5}$

For safety of donors, it is recommended that whole blood donated shall not exceed $13 \%$ of blood volume: e.g. a donor weighing $45 \mathrm{~kg}$ to donate $350 \mathrm{ml}$ and those weighing $50 \mathrm{~kg}$ to donate $450 \mathrm{ml}$ (age of 18 to 60 years). ${ }^{6}$ With a time frame of 10 to 20 minutes in one setting, repetition can be 12 weeks ( 3 months) for males and 16 weeks (4 months) for females. ${ }^{7}$ Unfortunately, there has been a diminishing external support to regional transfusion services in most of sub-Sharan African countries. As a result, the end volume of blood available and safety ${ }^{8}$ has remained to be of challenge ${ }^{9}$ in achieving the goal of universal health coverage. ${ }^{10}$

The above requirement can be met from blood donation, where donors are classified as Voluntary Non-Remunerated Blood Donors (VNRBD), Family replacement, Remunerated / Paid / Commercial / Professional donors, and Autologous Blood Donors. ${ }^{11}$ However, the safest blood donors are VNRBD from low-risk populations [10]. Volunteers aged between 24 and 35 years are considered to give the most effective blood. Majority of them being in secondary school training or college. ${ }^{12}$

Despite the highest population and highest blood demand in East Africa, Tanzania presents a lowest blood collection units per a population of 1000 people i.e. Tanzania (3.6), Kenya (4.1) and Uganda (6.3). ${ }^{13}$. In 2017, Tanzanian National Blood Transfusion Services 
(NBTS) reported an estimate of only $36 \%$ of all blood need being met. ${ }^{14}$ Main source for blood supply in the hospitals in Tanzania comes straight from donors who non - NBTS blood banks. ${ }^{15}$ About $79 \%$ of blood collected in Tanzania by NBTS (blood bank) are from VNRBD and the remaining $21 \%$ from family replacement. ${ }^{16}$ Strengthening VNRB campaigns has been continuously recommended for public institutions in Tanzania. ${ }^{17}$

One of the most important VNRBD groups are college students based on their age and knowledge. ${ }^{12,18,19}$ General factors influencing blood donation vary from region to region by attitudes, willing to donate, age, gender, knowing a person who has donated blood, knowledge of the amount of blood donated, willingness to donate in the future, and post-donation reward..$^{20,21}$ Lately, medical students have presented impressive knowledge, awareness and attitude on blood donation in Africa. ${ }^{22,23}$ Unfortunately, blood donation is not more than $95 \%$ among medical students with questionable internal variations among medical students. ${ }^{24}$

The main aim of the study was to assess the knowledge, attitude, willingness for the future blood donation among medical students of southern, Tanzania.

\section{Methods}

\section{Study design, the aim, and setting of the study}

The quantitative descriptive cross-sectional study design was conducted in Songea town, Ruvuma region of southern Tanzania The study aimed at assessing the knowledge, attitude and practice for medical students in volunteering for blood donations that can save lives during pregnancy, birth, anemia in children and hematological conditions. The study was conducted at a Teaching Medical Hospital of Archbishop James University College, AJUCO at Peramiho Medical Campus. Today all of these students are academically registered at University of Dares Salaam, Mbeya College of Health and Allied Sciences, UDSM-MCHAS).

\section{Setting, sampling and study duration}

A frame list of all students attending medical degree training was created. Special code for each student was created. Medical students who were willing to participate in the study were invited and second list of eligible students was generated. All students willingly to participate were randomly selected by a simple random sampling technique. Those who were sampled were given written consent and interviewed using structured questionnaire. Data was collected from $10^{\text {th }}$ March to $30^{\text {th }}$ June 2018.

\section{Eligibility}

All medical students who were present and willing to participate in the study were included in the participant's list. All medical students who were absent during data collection, or those who were present during data collection but did not consent for the participation were excluded. Students who were present during data collection and participated in the study but did not complete filling of questionnaire were also excluded from the study.

\section{Data collection tools, data management and analysis}

Data was collected by using as self-administered structured questionnaire. Data was entered and stored in SPSS database using summary codes for all variable values. A code book was guiding investigators to do data cleaning for reviews of errors and incompleteness. The quantitative analysis of data was done using IBM Corp. SPSS Version 24.0 of 2016 was used for data analysis. Description of the proportions for demographic summary, proportions for awareness, knowledge, attitude and willingness for blood donations were done and measures of associations (odds ratio) for ever donating blood and factors associated was analysed.

\section{Ethics}

Ethical review and permission was granted by the Institutional AJUCO - Ethical Review Committee. Information on the design of the study, benefits and chances if there are risks to participate was given in writing. The study pointed out clearly that there are no any anticipated risks and all information shared will be recorded, stored and analyzed with a strict confidentiality. The information that data will be stored using ID codes and not names was given orally and writing. Informed consent was granted by students before data collection.

\section{Results}

From a total of 662 medical students registered at AJUCO, where none of students were in first year (MD1), 84 students were in a second year (MD2), 328 from MD3, 100 from MD4 and 69 students from MD5. There were $81 \mathrm{MD} 3$ students attending clinical training at another teaching hospital ( $>300 \mathrm{~km}$ away) and a total of 307 students were not willing to participate. Finally, a total of 274 medical students (54 from MD2, 120 from MD3, 50 from MD4, and 50 from MD5) given questionnaires but 98 students presented with incomplete filled questioners.

\section{Demographic characteristics of participants.}

A final sample of 176 students were available for final analysis, after reviewing the completeness of questionnaire and data cleaning. Among the 176 participants, the average age $25.8( \pm 3.6)$ years, ranging from 20 to 44 years and the majority, $152(86.4 \%)$ ranged from 20 to 29 years. Details of the demographic characteristics are shown in Table 1.

\section{Awareness of blood donation}

The information on the source of awareness of Blood donation among students is shown in the Table 2.

\section{Knowledge on blood donation}

Majority of the participants 134 (76.3\%) knew their blood groups $96(54.4 \%)$ knew the minimum frequency that a donor should donate per year, $113(64.2 \%)$ had no knowledge on the safe amount of blood volume that not more than which should be donated also $126(71.6 \%)$ had no knowledge of amount of time required for blood donation process at one on set. The overall knowledge of common blood groups, groups of people that can donate blood and knowledge of TTI's was generally impressive as shown in Table 3.

\section{Attitude towards blood donation}

The attitude of the medical students towards blood donation was quite good $159(90.3 \%)$ also $135(77 \%)$ perceived voluntarily donated blood to be the best blood source, furthermore most of the participants believed temporary weakness as the common post donation effect as shown in Table 4. 
Table I Demographic Characteristics of the Participants

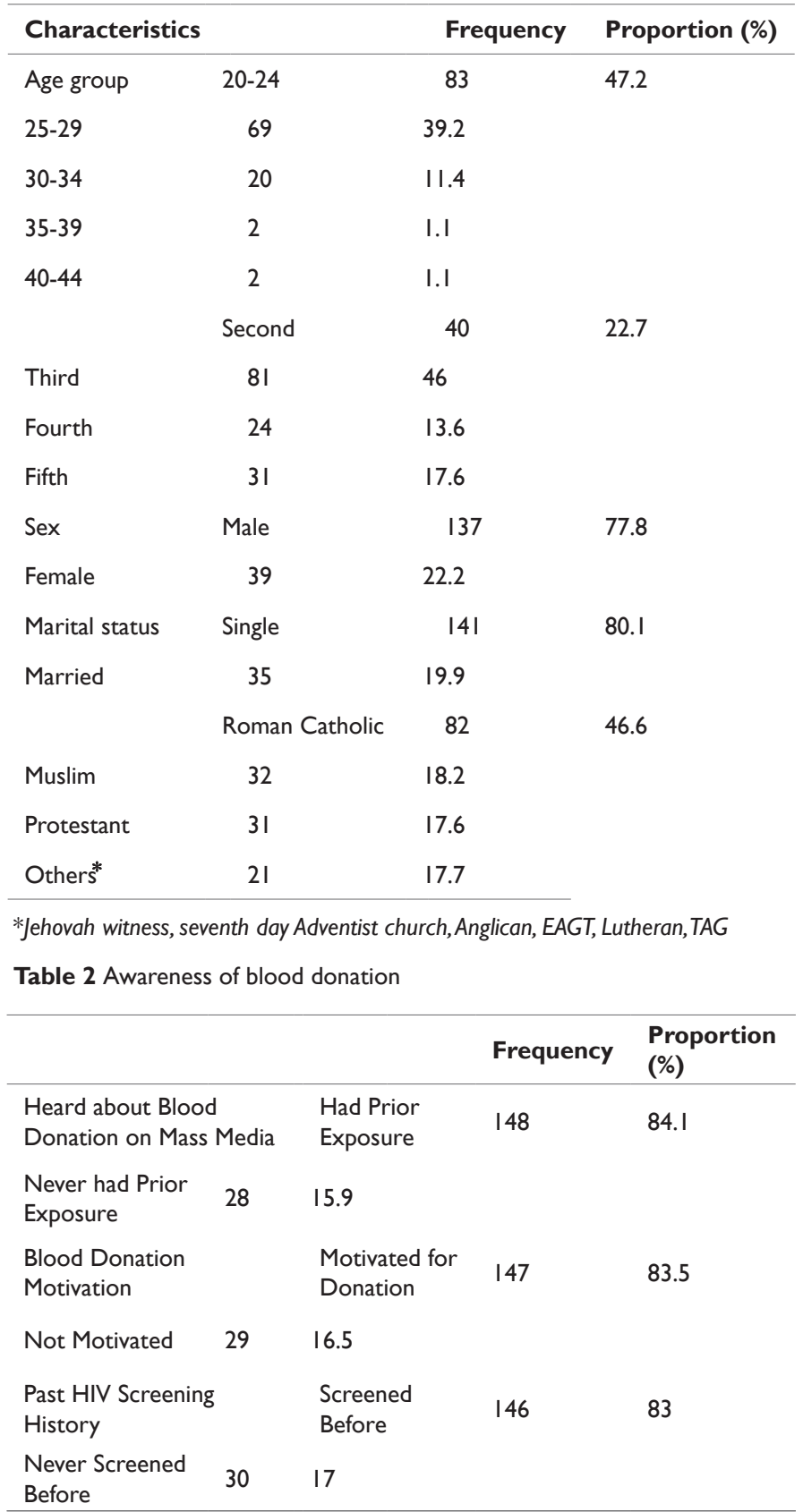

\section{Practice of Blood Donation}

Concerning the practice of blood donation among students, 80 $(45.5 \%)$ of the respondents they at least donated blood once in their life time. Among those who donated 66 (82.5\%) of those being out of volunteering. Regular blood donors were 46 (57.5\%) out of those who ever donated blood as shown in Table 5 .

\section{Willingness of participation in next blood donation event}

Majority of respondents $133(75.6 \%)$ were willing participate in next blood donation events or whenever they are called. The major reasons of not donating blood were; unfit to donate, fear of needle and the need to donate for a friend/relative in future $34.9 \%, 27.9 \%, 18.6 \%$ respectively Figure 1.

Table 3 Participant's knowledge on blood donation

\begin{tabular}{|c|c|c|c|}
\hline \multicolumn{2}{|l|}{ Characteristics } & \multirow{2}{*}{$\begin{array}{l}\text { Frequency } \\
4\end{array}$} & \multirow{2}{*}{$\begin{array}{l}\text { Proportion } \\
\text { (\%) } \\
2.3\end{array}$} \\
\hline \multirow{8}{*}{$\begin{array}{l}\text { Knowledge on } \\
\text { Common blood } \\
\text { groups }\end{array}$} & $A+$ & & \\
\hline & $\mathrm{B}+$ & 7 & 4.0 \\
\hline & $A B+$ & 12 & 6.8 \\
\hline & $\mathrm{O}+$ & 50 & 28.4 \\
\hline & O- & 5 & 2.8 \\
\hline & Positives ${ }^{\#}$ & 46 & 26.1 \\
\hline & All & 52 & 29.5 \\
\hline & $A+$ & 26 & 14.8 \\
\hline \multirow{8}{*}{$\begin{array}{l}\text { Knowledge on } \\
\text { Participant's } \\
\text { blood group }\end{array}$} & A- & I & 0.6 \\
\hline & $\mathrm{B}+$ & 26 & 14.8 \\
\hline & B- & I & 0.6 \\
\hline & $A B+$ & 13 & 7.4 \\
\hline & $A B-$ & 2 & I.I \\
\hline & $\mathrm{O}+$ & 55 & 31.3 \\
\hline & O- & 10 & 5.7 \\
\hline & Don't know & 39 & 22.2 \\
\hline \multirow{4}{*}{$\begin{array}{l}\text { Knowledge on if } \\
\text { blood transfusion } \\
\text { can cause } \\
\text { infection }\end{array}$} & Forgotten & 3 & 1.7 \\
\hline & knew & 170 & 96.6 \\
\hline & Didn't know & 6 & 3.4 \\
\hline & $\begin{array}{l}\text { HIV Can be } \\
\text { transmitted }\end{array}$ & 175 & 99.4 \\
\hline \multirow{9}{*}{$\begin{array}{l}\text { Knowledge on } \\
\text { Transfusion } \\
\text { Transmissible } \\
\text { Infections, TTI's }\end{array}$} & $\begin{array}{l}\text { HIV Can't be } \\
\text { transmitted }\end{array}$ & I & 0.6 \\
\hline & $\begin{array}{l}\text { HCV Can be } \\
\text { transmitted }\end{array}$ & 155 & 88.1 \\
\hline & $\begin{array}{l}\text { HCV Can't be } \\
\text { transmitted }\end{array}$ & 2 & 11.9 \\
\hline & $\begin{array}{l}\text { HBV Can be } \\
\text { transmitted }\end{array}$ & 170 & 96.6 \\
\hline & $\begin{array}{l}\text { HBV Can't be } \\
\text { transmitted }\end{array}$ & 6 & 3.4 \\
\hline & $\begin{array}{l}\text { Syphilis Can be } \\
\text { transmitted }\end{array}$ & 123 & 69.9 \\
\hline & $\begin{array}{l}\text { Syphilis Can't be } \\
\text { transmitted }\end{array}$ & 53 & 30.1 \\
\hline & $\begin{array}{l}\text { Malaria Can be } \\
\text { transmitted }\end{array}$ & 99 & 56.3 \\
\hline & $\begin{array}{l}\text { Malaria Can't be } \\
\text { transmitted }\end{array}$ & 77 & 43.8 \\
\hline
\end{tabular}


Table Continued

\begin{tabular}{|c|c|c|c|}
\hline Characteristics & & Frequency & $\begin{array}{l}\text { Proportion } \\
\text { (\%) }\end{array}$ \\
\hline \multirow{7}{*}{$\begin{array}{l}\text { Knowledge on } \\
\text { Frequency of } \\
\text { blood donation } \\
\text { per year }\end{array}$} & Weekly & 2 & I.I \\
\hline & Monthly & 7 & 4.0 \\
\hline & Three monthlies & 96 & 54.5 \\
\hline & Six monthlies & 30 & 17.0 \\
\hline & Annually & 6 & 3.4 \\
\hline & Others & I & 0.6 \\
\hline & Don't know & 34 & 19.3 \\
\hline \multirow{3}{*}{$\begin{array}{l}\text { Knowledge on } \\
\text { safe amount of } \\
\text { blood volume } \\
\text { donation at one } \\
\text { on set }\end{array}$} & $<500 \mathrm{ml}$ & 63 & 35.8 \\
\hline & $500-1000 \mathrm{ml}$ & 60 & 34.1 \\
\hline & Don't know & 53 & 30.1 \\
\hline \multirow{9}{*}{$\begin{array}{l}\text { Amount of time } \\
\text { required for } \\
\text { blood donation } \\
\text { process }\end{array}$} & 20-60minutes & 50 & 28.4 \\
\hline & $<20$ minutes & 32 & 18.2 \\
\hline & Don't know & 94 & 53.4 \\
\hline & Men can donate & 176 & 100.0 \\
\hline & Men can't donate & 0 & 0 \\
\hline & Women can donate & $17 \mid$ & 97.2 \\
\hline & Women can't donate & 5 & 2.8 \\
\hline & Healthy can donate & 176 & 100.0 \\
\hline & Healthy can't donate & 0 & 0 \\
\hline \multirow{6}{*}{$\begin{array}{l}\text { Knowledge on } \\
\text { groups of people } \\
\text { that can donate } \\
\text { blood }\end{array}$} & $\begin{array}{l}\text { Young<18 years can } \\
\text { donate }\end{array}$ & 16 & 9.1 \\
\hline & $\begin{array}{l}\text { Young< } 18 \text { years can't } \\
\text { donate }\end{array}$ & 160 & 90.9 \\
\hline & $\begin{array}{l}\text { Old>60 years can } \\
\text { donate }\end{array}$ & 8 & 4.5 \\
\hline & $\begin{array}{l}\text { Old }>60 \text { years can't } \\
\text { donate }\end{array}$ & 168 & 95.5 \\
\hline & Diseased can donate & 2 & I.I \\
\hline & Diseased can't donate & 174 & 98.9 \\
\hline
\end{tabular}

\#Respondents who selected all $\mathrm{A}+, \mathrm{B}+, \mathrm{AB}+, \mathrm{O}+$ as the common blood groups which they knew

\section{Factors associated with blood donation}

The factors that associated with blood donation were age above 30 years $(\mathrm{OR}=0.18, \mathrm{p}<0.001)$ where the respondents aged between 20 29 years of age were $82 \%$ had less chance to donate blood than those 30 and above. Another factor is the male sex $(\mathrm{OR}=3.69, \mathrm{p}=0.001)$ where males were almost four times more associated to donate blood than females. The past HIV screening had two and half chance for blood donation $(\mathrm{OR}=2.59, \mathrm{p}=0.029)$. The knowledge of one's own blood group had five times more chance to donate blood than medical students who do not know their blood group $(\mathrm{OR}=4.86, \mathrm{P}<0.001)$. The knowledge of the safe duration of time of blood donation in one setting had two and half more chance to donate blood than medical students who do not know the safe duration for blood donation $(\mathrm{OR}=2.42, \mathrm{P}=0.024)$. Details of other factors and their measures of association are shown in Table 6.
Table 4 The Attitude towards Blood Donation

\begin{tabular}{|c|c|c|c|}
\hline \multicolumn{2}{|c|}{ Attitude for blood donation } & \multirow{2}{*}{$\begin{array}{l}\text { Frequency } \\
159\end{array}$} & \multirow{2}{*}{$\begin{array}{l}\text { Proportion } \\
\text { (\%) }\end{array}$} \\
\hline \multirow{3}{*}{$\begin{array}{l}\text { General feeling } \\
\text { towards blood } \\
\text { donation }\end{array}$} & Good practice & & \\
\hline & Bad practice & 3 & 1.7 \\
\hline & $\begin{array}{l}\text { It is a neutral } \\
\text { practice }\end{array}$ & 14 & 8.0 \\
\hline \multirow{5}{*}{ Best blood source } & $\begin{array}{l}\text { Voluntarily blood } \\
\text { donation }\end{array}$ & 135 & 76.7 \\
\hline & $\begin{array}{l}\text { Family } \\
\text { replacement } \\
\text { donation }\end{array}$ & 18 & 10.2 \\
\hline & Self-donation & 10 & 5.7 \\
\hline & $\begin{array}{l}\text { Remunerated / } \\
\text { paid donor }\end{array}$ & 3 & 1.7 \\
\hline & Don't know & 10 & 5.7 \\
\hline \multirow{3}{*}{$\begin{array}{l}\text { Adverse effects for } \\
\text { blood donor during/ } \\
\text { after donation }\end{array}$} & $\begin{array}{l}\text { There are adverse } \\
\text { effects }\end{array}$ & 125 & 71.0 \\
\hline & $\begin{array}{l}\text { There is no } \\
\text { adverse effects }\end{array}$ & 36 & 20.5 \\
\hline & Don't know & 15 & 8.5 \\
\hline \multirow{6}{*}{$\begin{array}{l}\text { Post blood donation } \\
\text { effects }\end{array}$} & $\begin{array}{l}\text { Temporary } \\
\text { weakness }\end{array}$ & 134 & 76.1 \\
\hline & Contract infection & 13 & 7.4 \\
\hline & Fall sick & 3 & 1.7 \\
\hline & All of the above & 17 & 9.7 \\
\hline & No effect & I & 0.6 \\
\hline & Don't know & 8 & 4.5 \\
\hline
\end{tabular}

Table 5 Practice of Blood Donation

\begin{tabular}{|c|c|c|c|}
\hline Practice & & Frequency & $\begin{array}{l}\text { Proportion } \\
\text { (\%) }\end{array}$ \\
\hline \multirow{2}{*}{$\begin{array}{l}\text { Previous } \\
\text { experience of } \\
\text { blood donation } \\
(\mathrm{N}=\mid 76)\end{array}$} & Ever donated blood & 80 & 45.5 \\
\hline & $\begin{array}{l}\text { Never donated } \\
\text { blood }\end{array}$ & 96 & 54.5 \\
\hline \multirow{3}{*}{$\begin{array}{l}\text { Reason for } \\
\text { donating blood } \\
\text { for those who } \\
\text { ever donated } \\
(\mathrm{N}=80)\end{array}$} & Voluntary & 66 & 82.5 \\
\hline & $\begin{array}{l}\text { A friend / relative } \\
\text { needed blood }\end{array}$ & 13 & 16.25 \\
\hline & $\begin{array}{l}\text { To know my blood } \\
\text { status }\end{array}$ & I & 1.25 \\
\hline \multirow{3}{*}{ Regular donatior } & Yes & 46 & 57.5 \\
\hline & & & \\
\hline & No & 33 & 42.5 \\
\hline \multirow{4}{*}{$\begin{array}{l}\text { Regular donor's } \\
\text { frequency }\end{array}$} & $<\mid$ time a year & 42 & 23.9 \\
\hline & I-3 times a year & 17 & 9.7 \\
\hline & $>3$ times a year & 7 & 4.0 \\
\hline & inapplicable ${ }^{* *}$ & 110 & 62.5 \\
\hline
\end{tabular}




\begin{tabular}{llll} 
Table Continued & & Frequency & $\begin{array}{l}\text { Proportion } \\
\text { (\%) }\end{array}$ \\
\hline Practice & Yes & 133 & 75.6 \\
$\begin{array}{l}\text { Willingness to } \\
\text { donate blood in } \\
\text { future }(\mathrm{N}=176)\end{array}$ & No & 43 & 24.4 \\
& $\begin{array}{l}\text { My religion forbids it } \\
\text { Need to donate to } \\
\text { friend or relative in } \\
\text { future }\end{array}$ & 3 & 7 \\
$\begin{array}{l}\text { Reasons for not } \\
\text { donating }\end{array}$ & $\begin{array}{l}\text { Unfit to donate } \\
\text { (N=43) }\end{array}$ & 15 & 18.6 \\
& $\begin{array}{l}\text { Fear of needle } \\
\text { Donated blood } \\
\text { may be donated to } \\
\text { others }\end{array}$ & 12 & 34.9 \\
\hline
\end{tabular}

* *ver donated blood $\mathrm{N}=\mid 76$, includes those who never donated and those who donated only once in their life time.

\section{Discussion}

Our study has presented findings that medical students in Songea, Ruvuma region of Southern Tanzania to have high awareness blood donation and high knowledge of the procedures and benefits blood donation.

Medical students in Southern Tanzania presented a proportion of $86.4 \%$ medical students aged $20-29$ years. The majority of students were third years, mainly males $(77.8 \%)$. About (84.1) had previous exposure, $83.5 \%$ motivated and about $83 \%$ were previously screened for HIV and though their can give blood to save lives in the hospitals.

We learned that $76.3 \%$ of medical students from Southern Tanzania were aware of the importance of knowing blood groups. They think this important information is a key life-saving knowledge when there is an emergence. This proportion was relatively higher compared that of $64 \%$ from Kilimanjaro, Northern Tanzania that included both medical and non-medical students of Kilimanjaro with odds ratio of 11.5, $\mathrm{p}<0.0001) .{ }^{12}$ This level of knowledge is however of lower proportion when compared to knowledge of blood groups among medical students from Adama University in Ethiopia (91.4\%), ${ }^{22}$ and Khartoum, $98.2 \% .{ }^{24}$ About $54.4 \%$ knew the minimum frequency that a donor should donate per year this is lower compared to that reported from Gondar, Ethiopia in which $67.8 \%$ had a correct knowledge on this aspect. ${ }^{23}$ The knowledge of the blood donation duration and past HIV screening were also significant factors associated with student blood donations.

Table 6 Factors associated with blood donations

\begin{tabular}{|c|c|c|c|c|c|c|}
\hline & & \multicolumn{5}{|c|}{ Experience for blood donation } \\
\hline \multicolumn{2}{|c|}{ Factors for blood donation } & $\begin{array}{l}\text { Ever donated } \\
\text { Freq (\%) }\end{array}$ & $\begin{array}{l}\text { Never } \\
\text { donated } \\
\text { Freq (\%) }\end{array}$ & $\begin{array}{l}\text { (100\% for each } \\
\text { row) }\end{array}$ & $\begin{array}{l}\text { P-value } \\
(\alpha=0.05)\end{array}$ & $\begin{array}{l}\text { Odds Ratio (95\%, } \\
\text { Confidence interval) }\end{array}$ \\
\hline Age & $20-29$ & $62(40.8)$ & $90(59.2)$ & 152 & & 0.18 \\
\hline \multirow[t]{2}{*}{ Sex } & Male & $72(52.6)$ & $65(47.4)$ & 137 & & 3.69 \\
\hline & Female & $9(23.1)$ & $30(76.9)$ & 39 & 0.001 & $(1.63-8.35)$ \\
\hline Past HIV screening & Ever screened & $73(49.7)$ & $74(50.3)$ & 147 & & 2.59 \\
\hline \multirow[t]{2}{*}{$\begin{array}{l}\text { Knowing own blood } \\
\text { group }\end{array}$} & Knew & $73(54.1)$ & $62(45.9)$ & 135 & $<0.001$ & 4.86 \\
\hline & Didn't know & $8(19.5)$ & $33(80.5)$ & 41 & & $(2.09-11.28)$ \\
\hline \multirow[t]{2}{*}{ Knowing safe duration } & Knew & $21(63.6)$ & $12(36.4)$ & 33 & & 2.42 \\
\hline & Didn't know & $60(42.0)$ & $83(58,0)$ & 143 & 0.024 & $(1.10-5.29)$ \\
\hline \multirow[t]{2}{*}{ Academic Level** } & Non-clinical & $58(47.9 \%)$ & $63(52.1 \%)$ & 121 & 0.451 & $1.28 \mathrm{I}$ \\
\hline & Clinical & $23(48.1 \%)$ & $32(58.2 \%)$ & 55 & & $(0.67-2.43)$ \\
\hline \multirow[t]{2}{*}{$\begin{array}{l}\text { Exposure of blood } \\
\text { donation programs }\end{array}$} & Exposed & 72 (48.6\%) & 76 (5I.4\%) & 148 & 0.18 & 2 \\
\hline & Not exposed & $9(32.1 \%)$ & 19 (67.9\%) & 28 & & $(0.85-4.70)$ \\
\hline $\begin{array}{l}\text { Blood donation } \\
\text { motivation }\end{array}$ & Not motivated & $9(3 \mid \%)$ & $20(69 \%)$ & 29 & & $(0.91-4.99)$ \\
\hline
\end{tabular}




\begin{tabular}{|c|c|c|c|c|c|c|}
\hline & & \multicolumn{5}{|c|}{ Experience for blood donation } \\
\hline \multicolumn{2}{|c|}{ Factors for blood donation } & $\begin{array}{l}\text { Ever donated } \\
\text { Freq (\%) }\end{array}$ & $\begin{array}{l}\text { Never } \\
\text { donated } \\
\text { Freq (\%) }\end{array}$ & $\begin{array}{l}\text { (100\% for each } \\
\text { row) }\end{array}$ & $\begin{array}{l}\text { P-value } \\
(\alpha=0.05)\end{array}$ & $\begin{array}{l}\text { Odds Ratio ( } 95 \% \text {, } \\
\text { Confidence interval) }\end{array}$ \\
\hline \multirow[t]{2}{*}{$\begin{array}{l}\text { Knowing Safe frequency } \\
\text { of donation }\end{array}$} & know & 45 (46.4\%) & $52(53.6 \%)$ & 97 & 0.913 & 1.034 \\
\hline & Didn't know & $36(45.6 \%)$ & $43(54.4)$ & 79 & & $(0.57-1.87)$ \\
\hline \multirow[t]{2}{*}{$\begin{array}{l}\text { Knowledge on safe } \\
\text { blood volume }\end{array}$} & Know & $37(57.8 \%)$ & $27(42.2 \%)$ & 64 & & 2.11 \\
\hline & Didn't know & $44(39.3 \%)$ & $68(60.7 \%)$ & 112 & 0.018 & $(1.13-3.95)$ \\
\hline \multirow[t]{2}{*}{$\begin{array}{l}\text { Attitude toward blood } \\
\text { donation }\end{array}$} & satisfactory & 77 (48.4\%) & $82(51.6 \%)$ & 159 & 0.05 & 3.05 \\
\hline & unsatisfactory & $4(23.5 \%)$ & $13(51.6 \%)$ & 17 & & $(0.95-9.76)$ \\
\hline \multirow[t]{2}{*}{$\begin{array}{l}\text { Knowing best source } \\
\text { of blood }\end{array}$} & Knew & $68(50.4 \%)$ & $67(49.6 \%)$ & 135 & 0.036 & 2.1 \\
\hline & Didn't know & $13(31.7 \%)$ & $28(68.3 \%)$ & 41 & & (I.04-4.58) \\
\hline
\end{tabular}

** All students studied hematology in year 2 (MD2) but levels of knowledge for blood donations increases with clinical exposure from year 3 to year 5

When considering amount of blood to be drawn, we found $35.8 \%$ of students in Songea knew the safe amount of blood volume to be donated which was somewhat similar to what is reported from Kilimanjaro, North-West Tanzania (36.5\%), ${ }^{12}$ higher than experience in Khartoum, Sudan $(31 \%)^{24}$ but lower than medical students from Gondar, North-West Ethiopia where $44.7 \%$ of student had sufficient knowledge. ${ }^{23}$

The attitude of the medical students towards blood donation was fairly impressive at $90.3 \%$ this was consistent with findings in Kilimanjaro Tanzania (93.0\%) [12], this is due to the fact that medical students witness the needs of blood in their practices in hospital in saving the life of needy groups such as maternal hemorrhage.

Voluntarily donated blood was mentioned by medical students as the best source of blood at $77 \%$ slight lower compared to report from Rajkot University, India of $80 \%{ }^{25}$ and Gondar University, Ethiopia $(91.8 \%) .{ }^{23}$. Additionally, we learned that $71 \%$ of medical students in Southern Tanzania presented worries that after a moment of blood donation there could be some circulatory system side effects that were explained by Hinrichs in $2017^{26}$ This was unexpectedly higher compared to what was reported in India $(33.3 \%)^{27}$ and Ethiopia $(14.5 \%)^{23}$ [23]. Students also mentioned temporary weakness $(76.1 \%)$ reported as dizziness among medical student in Northern Tanzania, $(94.9 \%)$.

We found about half of student (45.5\%) had an experience of blood donation in primary or secondary school training. This was higher than experience reported in Sudan, ${ }^{24}$ Ethiopia, ${ }^{22,23,28}$ Kilimanjaro, ${ }^{12}$ Pakistan $^{29}$ and Northern India ${ }^{30,31}$ and Sothern India ${ }^{32}$ which ranged from $12.5 \%$ to $30 \%$. However, this proportion was lower than medical students at Nnamdi Azikiwe University 78.2\% ${ }^{33}$ Those who donated out of voluntarism were $82.5 \%$ which is higher than those reported in Solan, Northern India $(38.4 \%)^{31}$ but lower than that reported in Northern Tanzania $90.5 \% .^{12}$

Regular blood donors nearly similar to those in northern Tanzania $57.5 \%$ by $55 \%$ respectively ${ }^{12}$ but higher than Solan, Northern India $(43.4 \%){ }^{31}$ In this case we learnt that regular blood donation has remained to be of challenge. Thus, this finding reflect that a strong blood donation systems guided by determinants of blood donations is needed. ${ }^{34}$

With regards to willingness, the majority of students in Southern Tanzania $(75.6 \%)$ were willing participate in next blood donation events or whenever invited. This was a relative higher proportions compared to students of Khartum Sudan $53.8 \%{ }^{24}$ but lower than students at Gondar University in Ethiopia $(85.5 \%)^{28}$ and Northern Tanzania $(96 \%){ }^{12}$.

We noticed a major reason of not donating blood was respondents feeling medically unfit $(34.9 \%)$ as similarly described in southern India $(47.8 \%))^{32}$. This was a shocking paradox age as students aged 20-29 years were less likely to donate blood than those at 30 years and above. In contrast, literature from Ethiopia by Mulugeta showed age of $25-30$ years has four times will to donate blood than those at age 20-24 years significantly at $99 \%$ confident interval. ${ }^{23}$.

In southern Tanzania, medical students with male sex had higher wills to donate blood than female sex in consistent with Karachi, Pakistan. However, we found 4 times (male; female wills) to donate blood in southern Tanzania compared to 1.5 times (male; female wills) in Karachi, Pakistan. ${ }^{29}$ Surprisingly, Northern Tanzania literature showed males to have $48 \%$ lower odds of donating blood than girls at $95 \%$ confidence level. ${ }^{12}$ Other remaining literature has shown that male sex has a higher volunteering chances. ${ }^{16}$

We found that age of more than 30 years, male sex, knowing owns blood group, past HIV screening and knowledge safe duration of donating blood to be positively associated with blood donation willingness.

It is therefore anticipated that NBTS and MOHCDGEC can use this opportunity of blood donations from medical students. With a total of 8 medical university colleges in Tanzania training about 13,000 medical students a year. ${ }^{35}$ Tanzania can easily reach the WHO goal of $100 \%$ voluntary non-remunerated blood donation by scaling up medical students' awareness. In this perspective we also urge other African countries with high rates of maternal mortalities, blood disorders or high proportion of accidents to scale up blood donation through the use of medical students. 


\section{Study limitations}

This study design was a university campus based descriptive cross-section study that was not funded but motivated by Medical Students Association. It was part of the academic requirement for a degree of course of medicine Arch Bishop James University College, Peramiho Medical Campus in Songea town, Ruvuma region of Southern Tanzania. Data were collected in a short duration and had sample size limitation to recruit additional medical schools due to lack of enough funding.

\section{Conclusion}

Medical student offers an impressive attitude towards the practice of voluntary blood donation accompanied with a testified willing to participate once called to it. They present a high awareness, positive attitude, and high intention to donate blood. Medical students offer the low hanging fruits for high volume of safe blood collection. This is an opportunity to save more lives to meet the WHO goals for nonremunerated blood donations.

\section{Recommendations}

The NBTS and MOHCDGEC are urged to organize University Medical College events that will collect blood from medical students. To meet the WHO goal of $100 \%$ voluntary non-remunerated blood donation, other African countries have to scale up the use of medical students for blood donation.

\section{Declaration}

\section{Acknowledgments}

The authors are grateful to the Archbishop James University College, Peramiho Medical Campus an opportunity for the research and providing conducive environment in general. The authors are grateful for the support of administration of Archbishop James University College, Peramiho Medical Campus and the University of Dar es Salaam - Mbeya college of Health and Allied sciences for their unreserved cooperation in making this study be a fruitful work.

\section{Funding}

Not applicable.

\section{Availability of data and materials}

All relevant data are included in the manuscript. Data collection tool attached as a supplementary material. Availability of additional data and materials Data sets are available by a friendly request to the corresponding author.

\section{Authors' contributions}

MMS: Developed the concept note and design, acquisition of data, analysis, and interpretation of data as well as initial development of the manuscript. KBZ: Made substantial contributions to design, acquisition of data, analysis, and interpretation of data. BM: Has made substantial contributions to the analysis, interpretation of data and initial draft the manuscript and led the final write up of the manuscript. All the authors have been involved in drafting the manuscript and revising it critically for important intellectual content, and; have given final approval of the version to be published.

\section{Ethics}

Ethics approval and consent to participate Ethical clearance was granted by the Archbishop James University College - Ethical Review Committee as established by National Health Research Ethics Sub-Committee (NatHREC) of Tanzanian National Institute for Medical Research. Written consents were obtained from all study subjects with ethical review committee approval due to the fact that the data collected were not invasive with minimal health impact; hence, ascertained that the participation was voluntarily. The study participants' code numbers were used rather than personal identifiers. Finally, all questionnaires were kept for an intended purpose only.

\section{Consent for publication}

All participants have consented for publication of the result of this study (medical information, case description if needed and demographic summary without sharing names).

\section{Competing interests and Conflicts of Interests}

The authors declare that they have no competing neither the conflicts of interests.

\section{References}

1. WHO. Global Status Report on Blood Safety and Availability. Geneva, Switzerland; 2016.

2. Custer B, Zou S, Glynn SA, et al. Addressing gaps in international blood availability and transfusion safety in low- and middle-income countries: a NHLBI workshop. Transfusion. 2018;58(5):1307-1317.

3. WHO. Voluntary unpaid blood donations must increase rapidly to meet 2020 goal [Internet]. Newsletter. 2016.

4. WHO. International Federation of Red Cross and Red Crescent Societies. Towards 100\% Voluntary Blood Donation. A Global Framework for Action [Internet]. World Health Organization. Geneva: WHO Press; 2010.

5. Bates I, Chapotera GK, McKew S, et al. Maternal mortality in subSaharan Africa: the contribution of ineffective blood transfusion services. BJOG. 2008;115(11):1331-1339.

6. JPAC. Volume of donation [Internet]. Guidelines for the Blood Transfusion Services. Joint United Kingdom (UK) Blood Transfusion and Tissue Transplantation Services Professional Advisory Committee. 2019.

7. World Health Organization. Blood Donor Selection: Guidelines on Assessing Donor Sustainability for Blood Donation. Centers Dis Control Prev. 2012.

8. Ware A, Jacquot C, Tobian A, et al. Pathogen reduction and blood transfusion safety in Africa: strengths, limitations and challenges of implementation in low-resource settings. Vox Sang. 2018;113(1):312 .

9. Weimer A, Tagny C, Tapko J, et al. Blood transfusion safety in subSaharan Africa: A literature review of changes and challenges in the 21st century. Transfusion. 2019;59(1):412-427.

10. WHO, IFRC. Towards $100 \%$ voluntary blood donation: a global framework for action. Geneva, Switzerland; 2010.

11. WHO. Voluntary non-remunerated blood donation. Blood transfusion safety. 2019. 
12. Elias E, Mauka W, Philemon RN, et al. Knowledge, Attitudes, Practices, and Factors Associated with Voluntary Blood Donation among University Students in Kilimanjaro, Tanzania. J Blood Transfus. 2016;2016(Article ID 8546803):1-8.

13. Chevalier M, Kuehnert M, Basavaraju S, et al. Progress toward strengthening national blood transfusion services-14 countries. Morb Mortal Wkly Rep. 2016;65(5):115-119.

14. Juma A. Unmet need for blood: Challenges faced by NBTS. Nationa Blood Transfusion Services Tanzania, Personal Communication, 24 May 2017. Tanzania's Blood Services. Mamaye Fact Sheet. 2017

15. Drammeha B, De A, Bocka N, et al. Estimating Tanzania's National Met and Unmet Blood Demand From a Survey of a Representative Sample of Hospitals. Transfus Med Rev. 2018;32(1):36-42.

16. MoHCDGEC. National Blood Transfusion Service 2017/2018 Annual Report. Tanzania; 2018.

17. NBTS. Tanzania's Blood Services : Fact Sheet / Action to Address Challenges. Mamaye Website. Dar es salaam, Tanzania; 2017.

18. Raghuwanshi B, Pehlajani NK, Sinha MK. Voluntary Blood Donation among Students - A Cross-Sectional Study on Knowledge and Practice vs . Attitude. J Clin Diagnostic Res. 2016;10(10):18-22.

19. Ugwu A, Madu A, Efobi C, et al. Pattern of blood donation and characteristics of blood donors in Enugu, Southeast Nigeria. Niger $J$ Clin Pr. 2018;21(11):1438-1443.

20. Asamoah-Akuoko L, Hassall O, Bates I, et al. Blood donors' perceptions, motivators and deterrents in Sub-Saharan Africa - a scoping review of evidence. Br J Haematol. 2017;177(6):864-877.

21. Zanin TZ, Hersey DP, Cone DC, et al. Tapping into a vital resource : Understanding the motivators and barriers to blood donation in SubSaharan Africa. African J Emerg Med. 2016;6(2_:70-79.

22. Gebresilase HW, Fite RO, Abeya SG. Knowledge, attitude and practice of students towards blood donation in Arsi university and Adama science and technology university: a comparative cross sectional study. BMC Hematol. 2017;17:20.

23. Melku M, Asrie F, Shiferaw E, et al. Knowledge, Attitude and Practice Regarding Blood Donation among Graduating Undergraduate Health Science Students at the University of Gondar, Northwest Ethiopia. Ethiop J Heal Sci. 2018;28(5):571.

24. Mohammed H, Osman T. Voluntary Blood Donation among Medical Students in a Resource-limited Country. J Public Heal Dev Ctries. 2016;2(3):257-267.
25. Chauhan R, Kumar R, Thakur S. A study to assess the knowledge, attitude, and practices about blood donation among medical students of a medical college in North India. J Fam Med Prim Care. 2018;7(4):694-697.

26. Hinrichs A, Picker S, Schneider A, Lefering R, Neugebauer E, BS G. Effect of blood donation on well-being of blood donors. Transfus Med. 2008;18(1):40-48

27. Karmakar PR. Knowledge and Practice of Blood donation among Students in a Medical College in Kolkata. J Dent Med Sci. 2018;17(10):4-7.

28. Arage G, Ibrahim S, Adimasu E. Blood donation practice and its associated factors among health professionals of University of Gondar Hospital , Northwest Ethiopia : a cross sectional study. BMC Res Notes. 2017;10(1):294.

29. Ahmed Z, Zafar M, Khan AA, et al. Knowledge, Attitude and Practices about Blood Donation among Undergraduate Medical Students in Karachi. Infect Dis Ther. 2014;2(2):134.

30. Agravat, Amit G, Gauravi D, et al. Knowledge, Attitude, and Practice of Voluntary Blood Donation Among Medical Students of PDU Medical College Rajkot. Int J Curr Res. 2014;6(5):6839-6841.

31. Meinia SK, Kumar Y, Meinia A, et al. A study to assess the knowledge , attitude, and practices about voluntary blood donation amongst the undergraduate medical students in Solan, North India. Int J Med Sci Public Heal. 2016;5(12):2550-2554.

32. Sabu K, Ramya M, Binu VS, et al. Knowledge, Attitude and Practice on Blood Donation among Health Science Students in a university campus, south india. Online Journal of Health and Allied Sciences. 2011;10(2):10-12.

33. Nwabueze S, Nnebue C, Azuike E, et al. Perception of Blood Donation among Medical and Pharmaceutical Science Students of Nnamdi Azikiwe University, Awka. Open J Prev Med. 2014;04(07):515-522.

34. Godin G, Conner M, Sheeran P, et al. Determinants of repeated blood donation among new and experienced blood donors. Transfusion. 2007; 47(9):1607-1615.

35. TCU. Undergraduate Admission Guidebook for 2019/2020 Academic Year. Dar es salaam, Tanzania; 2019. 